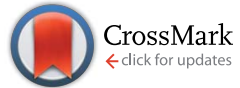

Cite this: Chem. Sci., 2016, 7, 4730

Received 3rd February 2016 Accepted 27th March 2016

DOI: $10.1039 / c 6 s c 00539 j$

www.rsc.org/chemicalscience

\section{Methane activation by gold-doped titanium oxide cluster anions with closed-shell electronic structures $\dagger$}

\author{
Yan-Xia Zhao, ${ }^{a}$ Xiao-Na Li, ${ }^{a}$ Zhen Yuan, ${ }^{\text {ab }}$ Qing-Yu Liu, ${ }^{\text {ab }}$ Qiang Shi*a \\ and Sheng-Gui He*a
}

\begin{abstract}
The reactivity of closed-shell gas phase cluster anions $\mathrm{AuTi}_{3} \mathrm{O}_{7}{ }^{-}$and $\mathrm{AuTi}_{3} \mathrm{O}_{8}{ }^{-}$with methane under thermal collision conditions was studied by mass spectrometric experiments and quantum chemical calculations. Methane activation was observed with the formation of $\mathrm{AuCH}_{3}$ in both cases, while the formation of formaldehyde was also identified in the reaction system of $\mathrm{AuTi}_{3} \mathrm{O}_{8}{ }^{-}$. The cooperative effect of the separated $\mathrm{Au}^{+}$and $\mathrm{O}^{2-}$ ions on the clusters induces the cleavage of the first $\mathrm{C}-\mathrm{H}$ bond of methane. Further activation of the second $\mathrm{C}-\mathrm{H}$ bond by a peroxide ion $\mathrm{O}_{2}{ }^{2-}$ leads to the formation of formaldehyde. This study shows that closed-shell species on metal oxides can be reactive enough to facilitate thermal $\mathrm{H}-\mathrm{CH}_{3}$ bond cleavage and the subsequent conversion.
\end{abstract}

\section{Introduction}

Methane, the major component of natural gas and shale gas, represents an important feedstock for the production of valueadded chemicals. ${ }^{1-6}$ However, the direct conversion of methane poses a serious challenge in contemporary catalysis owing to the significant energy required for $\mathrm{C}-\mathrm{H}$ bond cleavage. ${ }^{1}$ Many heterogeneous and homogeneous catalytic systems have been studied to transform methane, while it is challenging to uncover the elementary reactions and molecular level (ML) mechanisms associated with methane activation and conversion. $^{3-7}$ In the last decades, model investigations of the elementary reactions between methane and gas phase atomic clusters with state-of-the-art mass spectrometric experiments and quantum chemistry calculations have been serving as an important approach to discovering the ML mechanisms of methane activation and transformation. ${ }^{8-16}$ The identified mechanisms can be very useful for catalyst design and optimization. ${ }^{17-20}$

Many atomic clusters including oxides, ${ }^{8-11}$ carbides, ${ }^{21}$ noble metals, ${ }^{13-16}$ and so on have been identified to be able to activate methane under thermal collision conditions. Investigations of

${ }^{a}$ Beijing National Laboratory for Molecular Sciences, State Key Laboratory for Structural Chemistry of Unstable and Stable Species, Institute of Chemistry, Chinese Academy of Sciences, Beijing 100190, P. R. China. E-mail: shengguihe@iccas.ac.cn; qshi@iccas.ac.cn

${ }^{b}$ University of Chinese Academy of Sciences, Beijing 100049, P. R. China

$\dagger$ Electronic supplementary information (ESI) available: The detailed experimental and computational methods as well as additional experimental and computational results. See DOI: 10.1039/c6sc00539j these cluster systems have revealed three types of mechanism to activate the $\mathrm{C}-\mathrm{H}$ bond of methane:

$$
\begin{gathered}
{\left[\mathrm{MO}^{\cdot-}\right]+\mathrm{CH}_{4} \rightarrow\left[\mathrm{M}(\mathrm{O}-\mathrm{H})^{-}\right]+\mathrm{CH}_{3} \cdot} \\
{[\mathrm{M}]+\mathrm{CH}_{4} \rightarrow\left[\mathrm{H}-\mathrm{M}-\mathrm{CH}_{3}\right]} \\
{[\mathrm{ML}]+\mathrm{CH}_{4} \rightarrow\left[\mathrm{M}-\mathrm{CH}_{3}\right]+\mathrm{H}-\mathrm{L}}
\end{gathered}
$$

where $\mathrm{M}$ is usually a metal atom and $\mathrm{L}$ is a ligand bonded with $\mathrm{M}$. The atomic oxygen radical anions $\left(\mathrm{O}^{\cdot-}\right)$ were extensively identified to activate methane through hydrogen atom abstraction (Reaction (1) $)^{8-11,22}$ on many oxide clusters such as $\mathrm{V}_{4} \mathrm{O}_{10}{ }^{+},{ }^{23} \mathrm{Al}_{8} \mathrm{O}_{12}{ }^{+},{ }^{24}$ and $\mathrm{AuNbO}_{3}{ }^{+} \cdot{ }^{25}$ The coordinatively unsaturated metal atoms in naked and ligated metal species such as $\mathrm{Au}_{2}{ }^{+},{ }^{14} \mathrm{Pt}_{n},{ }^{+}{ }^{15} \mathrm{PtCH}_{3}{ }^{+},{ }^{26}$ and $\mathrm{TaC}_{n}{ }^{+}$(ref. 21) can activate methane through oxidative addition (Reaction (2)). ${ }^{9,22,27}$ The mechanism of $\sigma$-bond metathesis (Reaction (3)) ),22 $^{9}$ was reported for a few simple mononuclear systems such as $\mathrm{NiF}^{+}$(ref. 28) and $\mathrm{HTiO}^{+}$ (ref. 29) in which the $\sigma$-bonded ligand can be replaced through a reaction with the $\sigma$-bond of the incoming $\mathrm{CH}_{4}$. Herein, we report a new mechanism of methane activation by gas phase atomic clusters (Reaction (4)):

$$
\left[\mathrm{M}^{+} \cdots \mathrm{O}^{2-}\right]+\mathrm{CH}_{4} \rightarrow\left[\mathrm{CH}_{3}-\mathrm{M} \cdots(\mathrm{O}-\mathrm{H})^{-}\right]
$$

where the metal cation $\mathrm{M}^{+}$is separated from the oxygen anion $\mathrm{O}^{2-}$ on polynuclear metal oxide clusters and the cooperation of the two ions with counter polarity cleaves the $\mathrm{C}-\mathrm{H}$ bond of methane.

The ability of two atoms with different polarity to promote chemical activity of atomic clusters in reactions with small molecules has been previously identified in the literature. 
Castleman, Khanna, and their co-workers have reported that a complementary active site composed of a pair of adjacent $\mathrm{Al}$ atoms that respectively act as a Lewis acid and Lewis base can activate a variety of polar molecules such as water, alcohols, aldehydes, and thiols. ${ }^{30-33}$ Recently, we have found that a pair of non-adjacent ions $\mathrm{Au}^{+} \cdots \mathrm{O}^{2-}$ on $\mathrm{AuCeO}_{2}{ }^{+}$and $\mathrm{AuCe}_{2} \mathrm{O}_{4}{ }^{+}$cations can activate the non-polar dihydrogen. ${ }^{34}$ However, these clusters are still not reactive enough to activate methane. This study reports that the cooperation of the separated $\mathrm{Au}^{+}$and $\mathrm{O}^{2-}$ ions on gold-doped titanium oxide clusters $\mathrm{AuTi}_{3} \mathrm{O}_{7}{ }^{-}$and $\mathrm{AuTi}_{3} \mathrm{O}_{8}{ }^{-}$ can bring about methane activation at thermal energies. Subsequent conversion of methane to a stable organic compound, formaldehyde, has also been identified. It is noteworthy that for the thermal activation of methane, most of the reactive clusters reported have open-shell electronic structures and the very few reactive species with closed-shell electronic structures are all mononuclear cations. ${ }^{26,29}$ The cluster anions were generally found to be much less reactive than the corresponding cations in the reactions with methane..$^{\mathbf{1 0 , 1 3 , 1 6}}$ For the first time, we report thermal methane activation by cluster anions with closed-shell electronic structures.

\section{Results}

\section{Reactivity of $\mathrm{AuTi}_{3} \mathrm{O}_{7}{ }^{-}$and $\mathrm{AuTi}_{3} \mathrm{O}_{8}{ }^{-}$with methane}

The $\mathrm{AuTi}_{3} \mathrm{O}_{7}{ }^{-}$and $\mathrm{AuTi}_{3} \mathrm{O}_{8}{ }^{-}$cluster anions were prepared by a reaction of $\mathrm{O}_{2}$ with metal plasmas generated by laser vaporization of a solid disk compressed with $\mathrm{Au}$ and ${ }^{48} \mathrm{Ti}$ powders. The clusters of interest were mass-selected by a quadrupole mass filter and entered into a linear ion trap reactor, where they were thermalized by collisions with a pulse of He gas (maximal instantaneous pressure around 2-4 $\mathrm{Pa}$ ) and then interacted with a pulse of $\mathrm{CH}_{4}, \mathrm{CD}_{4}$, or $\mathrm{CH}_{2} \mathrm{D}_{2}$ for a period of time. ${ }^{35}$ Upon the interaction of $\mathrm{AuTi}_{3} \mathrm{O}_{7}{ }^{-}$with $50 \mathrm{mPa} \mathrm{CH}_{4}$ for about $1.07 \mathrm{~ms}$ (Fig. 1b), a strong product peak that can be assigned to $\mathrm{Ti}_{3} \mathrm{O}_{7} \mathrm{H}^{-}$ was observed, suggesting the following reaction channel:

$$
\mathrm{AuTi}_{3} \mathrm{O}_{7}^{-}+\mathrm{CH}_{4} \rightarrow \mathrm{Ti}_{3} \mathrm{O}_{7} \mathrm{H}^{-}+\mathrm{AuCH}_{3}
$$

The isotopic labelling experiments with $\mathrm{CD}_{4}$ (Fig. 1c) and $\mathrm{CH}_{2} \mathrm{D}_{2}$ (Fig. 1d) confirmed the above reaction. The generation of $\mathrm{Ti}_{3} \mathrm{O}_{7} \mathrm{D}^{-}$was observed from $\mathrm{AuTi}_{3} \mathrm{O}_{7}{ }^{-}+\mathrm{CD}_{4}$ while both $\mathrm{Ti}_{3} \mathrm{O}_{7} \mathrm{H}^{-}$and $\mathrm{Ti}_{3} \mathrm{O}_{7} \mathrm{D}^{-}$were produced from $\mathrm{AuTi}_{3} \mathrm{O}_{7}{ }^{-}+\mathrm{CH}_{2} \mathrm{D}_{2}$. The inter- and intra-molecule isotopic effects were apparently observed. In addition to Reaction (5), a minor association reaction channel generating $\mathrm{AuTi}_{3} \mathrm{O}_{7} \mathrm{CH}_{4}{ }^{-}$(4\% of the total product ions) was also observed.

The $\mathrm{AuTi}_{3} \mathrm{O}_{8}{ }^{-}$cluster is much less reactive than $\mathrm{AuTi}_{3} \mathrm{O}_{7}{ }^{-}$ and a longer reaction time and higher methane pressures were used for $\mathrm{AuTi}_{3} \mathrm{O}_{8}{ }^{-}+\mathrm{CH}_{4}$ (Fig. 1f), in which the generation of $\mathrm{Ti}_{3} \mathrm{O}_{7} \mathrm{H}^{-}, \mathrm{Ti}_{3} \mathrm{O}_{8} \mathrm{H}^{-}, \mathrm{AuTi}_{3} \mathrm{O}_{6}{ }^{-}$, and $\mathrm{AuTi}_{3} \mathrm{O}_{7} \mathrm{H}_{2}{ }^{-}$was observed and the assignments were confirmed by the experiments with $\mathrm{CD}_{4}$ and $\mathrm{CH}_{2} \mathrm{D}_{2}$ (Fig. $1 \mathrm{~g}$ and $\mathrm{S} 1 \mathrm{ESI} \dagger$ ). In a reference experiment with $\mathrm{N}_{2}$ (Fig. 1e), the $\mathrm{AuTi}_{3} \mathrm{O}_{6}{ }^{-}$product was not generated, indicating that this product cluster in Fig. 1f and $g$ was due to a chemical reaction rather than collision induced dissociation

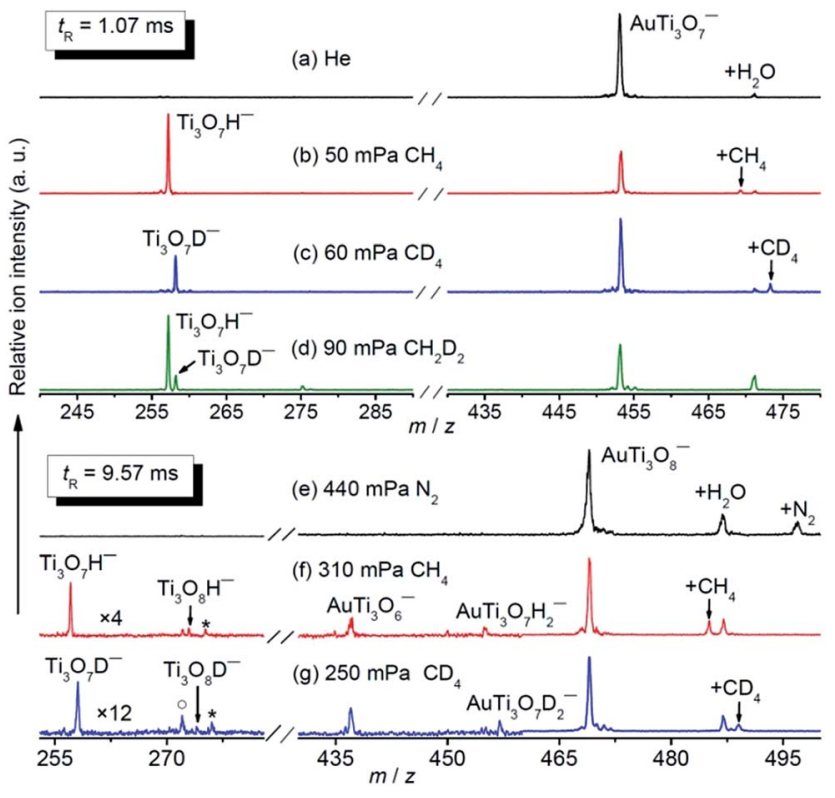

Fig. 1 Time-of-flight mass spectra for the reactions of mass selected $\mathrm{AuTi}_{3} \mathrm{O}_{7}{ }^{-}$and $\mathrm{AuTi}_{3} \mathrm{O}_{8}{ }^{-}$with $\mathrm{CH}_{4}$ (b and f), $\mathrm{CD}_{4}$ (c and g), $\mathrm{CH}_{2} \mathrm{D}_{2}$ (d), and $\mathrm{N}_{2}$ (e). The peaks marked with asterisks and hollow circles in panels $(f)$ and $(g)$ represent water adsorption products $\left(\mathrm{Ti}_{3} \mathrm{O}_{7} \mathrm{HH}_{2} \mathrm{O}^{-}\right.$or $\mathrm{Ti}_{3} \mathrm{O}_{7} \mathrm{DH}_{2} \mathrm{O}^{-}$) and $\mathrm{Ti}_{3} \mathrm{O}_{8}{ }^{-}$from collision induced dissociation, respectively. The peaks marked with $+\mathrm{X}\left(\mathrm{X}=\mathrm{H}_{2} \mathrm{O}, \mathrm{CH}_{4}, \mathrm{CD}_{4}\right.$, and $\left.\mathrm{N}_{2}\right)$ in panels $(\mathrm{a}-\mathrm{c})$ and $(\mathrm{e}-\mathrm{g})$ denote the association products with $\mathrm{AuTi}_{3} \mathrm{O}_{7}{ }^{-}$ and $\mathrm{AuTi}_{3} \mathrm{O}_{8}{ }^{-}$, respectively. The reactant gas pressures are shown. The reaction times $\left(t_{R}\right)$ are $1.07 \mathrm{~ms}$ for $(a-d)$ and $9.57 \mathrm{~ms}$ for $(e-g)$. The signal magnitudes below $\mathrm{m} / \mathrm{z} 460$ are amplified by 4 and 12 for (f) and (g), respectively.

(CID, such as $\mathrm{AuTi}_{3} \mathrm{O}_{8}{ }^{-}+\mathrm{CH}_{4} \rightarrow \mathrm{AuTi}_{3} \mathrm{O}_{6}{ }^{-}+\mathrm{O}_{2}+\mathrm{CH}_{4}$ ). In addition to molecular association, the following four reaction channels are suggested by the experiments:

$$
\begin{gathered}
\mathrm{AuTi}_{3} \mathrm{O}_{8}{ }^{-}+\mathrm{CH}_{4} \rightarrow \mathrm{Ti}_{3} \mathrm{O}_{8} \mathrm{H}^{-}+\mathrm{AuCH}_{3} \\
\mathrm{AuTi}_{3} \mathrm{O}_{8}{ }^{-}+\mathrm{CH}_{4} \rightarrow \mathrm{AuTi}_{3} \mathrm{O}_{7} \mathrm{H}_{2}{ }^{-}+\mathrm{CH}_{2} \mathrm{O} \\
\mathrm{AuTi}_{3} \mathrm{O}_{8}{ }^{-}+\mathrm{CH}_{4} \rightarrow \mathrm{Ti}_{3} \mathrm{O}_{7} \mathrm{H}^{-}+\mathrm{AuCH}_{3} \mathrm{O}\left(\mathrm{CH}_{2} \mathrm{O}+\mathrm{AuH}\right) \\
\mathrm{AuTi}_{3} \mathrm{O}_{8}{ }^{-}+\mathrm{CH}_{4} \rightarrow \mathrm{AuTi}_{3} \mathrm{O}_{6}{ }^{-}+\mathrm{CH}_{4} \mathrm{O}_{2}\left(\mathrm{CH}_{2} \mathrm{O}+\mathrm{H}_{2} \mathrm{O}\right)
\end{gathered}
$$

The branching ratios of generating $\mathrm{AuTi}_{3} \mathrm{O}_{8} \mathrm{CH}_{4}{ }^{-}(41 \%)$, $\mathrm{Ti}_{3} \mathrm{O}_{7} \mathrm{H}^{-}(35 \%)$, and $\mathrm{AuTi}_{3} \mathrm{O}_{6}{ }^{-}(15 \%)$ are much larger than those of $\mathrm{AuTi}_{3} \mathrm{O}_{7} \mathrm{H}_{2}{ }^{-}$(6\%) and $\mathrm{Ti}_{3} \mathrm{O}_{8} \mathrm{H}^{-}$(3\%) (Fig. 1f).

An atomic cluster often has different structural isomers with very different reactivities. ${ }^{29}$ The analysis of the methane-pressure dependent reactivity indicated that $(87 \pm 1) \%$ of the experimentally generated $\mathrm{AuTi}_{3} \mathrm{O}_{7}{ }^{-}$ions (Fig. S2 $\dagger$ ) and only $(37 \pm 4) \%$ of the $\mathrm{AuTi}_{3} \mathrm{O}_{8}{ }^{-}$ions (Fig. S3†) were reactive with $\mathrm{CH}_{4}$. For the reactive component of $\mathrm{AuTi}_{3} \mathrm{O}_{7}{ }^{-}$, the pseudo firstorder rate constant $\left(k_{1}\right)$ of Reaction $(5)$ is $(7.7 \pm 2.3) \times 10^{-11} \mathrm{~cm}^{3}$ per molecule per second, corresponding to a reaction efficiency $(\Phi)^{36}$ of $(7.7 \pm 2.3) \%$. The intra and inter-molecular kinetic isotope effects (KIEs) amount to $5.0 \pm 1.1$ and $4.5 \pm 1.3$, respectively. For the reactive component of $\mathrm{AuTi}_{3} \mathrm{O}_{8}{ }^{-}$, the summed $k_{1}$ value of Reactions (6)-(9) is $(1.0 \pm 0.3) \times 10^{-12} \mathrm{~cm}^{3}$ 
per molecule per second $[\Phi=(0.1 \pm 0.03) \%]$. The inter-molecular KIE amounts to $4.0 \pm 1.3$.

\section{Reaction mechanisms of $\mathrm{AuTi}_{3} \mathrm{O}_{7}{ }^{-}$and $\mathrm{AuTi}_{3} \mathrm{O}_{8}{ }^{-}$with $\mathrm{CH}_{4}$}

Density functional theory (DFT) calculations at the TPSS level, which shows the overall best performance in calculating several critical bond energies among the 18 tested methods (Table S1, ESI $\dagger$ ), have been conducted to explore the detailed reaction mechanisms. A Fortran code based on the genetic algorithm was used to search the global minimum structures of $\mathrm{AuTi}_{3} \mathrm{O}_{7}{ }^{-}$ as well as $\mathrm{AuTi}_{3} \mathrm{O}_{8}{ }^{-}$clusters with different spin multiplicities. ${ }^{37}$ To determine the lowest-energy isomers of $\mathrm{AuTi}_{3} \mathrm{O}_{7}^{-}$and $\mathrm{AuTi}_{3} \mathrm{O}_{8}{ }^{-}$, further single-point energy calculations with a highlevel quantum chemistry method of a restricted coupled-cluster method with single, double, and perturbative triple excitations $[\operatorname{RCCSD}(\mathrm{T})]$ have also been performed for the TPSS optimized structures. In the reaction pathway of $\mathrm{AuTi}_{3} \mathrm{O}_{8}{ }^{-}+\mathrm{CH}_{4}$, concomitant cleavage and formation of several chemical bonds are involved in important transition states. It is known that commonly used density functionals do not correctly describe the long- and mid-range dispersion interactions, which can influence the chemical reaction energies. ${ }^{38}$ Thus, TPSS functional calculated energies with dispersion corrections ${ }^{\mathbf{3 8}}$ are given throughout the reaction pathways.

The lowest-lying isomer of $\mathrm{AuTi}_{3} \mathrm{O}_{7}{ }^{-}$(Fig. 2 and $\mathrm{S}^{\dagger} \dagger$ ) has two terminally-bonded oxygen anions $\left(\mathrm{O}_{\mathrm{t}}{ }^{2-},-0.62 \mathrm{e}\right)$ and a one-fold coordinated gold cation $\left(\mathrm{Au}_{1 \mathrm{f}}{ }^{+},+0.42 \mathrm{e}\right)$. It is noteworthy that the superscripts " $2-$ " of $\mathrm{O}^{2-}$ and "+" of $\mathrm{Au}^{+}$denote the formal oxidation states rather than the net charges on the atoms. As marked in Fig. 2, the $\mathrm{Au}_{1 \mathrm{f}}{ }^{+}$cation is separated from the $\mathrm{O}_{\mathrm{t}}{ }^{2-}$ anions. The Au-side of $\mathrm{AuTi}_{3} \mathrm{O}_{7}{ }^{-}$is the least negatively charged, so it is expected that the $\mathrm{Au}_{1 \mathrm{f}}{ }^{+}$atom traps $\mathrm{CH}_{4}$ to form the encounter complex I1 with a significant binding energy (54 $\mathrm{kJ} \mathrm{mol}^{-1}$ ). Then the $\mathrm{CH}_{4}$ is delivered to be close to a $\mathrm{O}_{\mathrm{t}}^{2-}$ ion (TS1) so that the cleavage of one $\mathrm{C}-\mathrm{H}$ bond and the concomitant formation of one $\mathrm{Au}-\mathrm{CH}_{3}$ bond and one $\mathrm{O}-\mathrm{H}$ bond can take place. Such a process (I1 $\rightarrow$ TS1 $\rightarrow$ I2) is subject to an energy

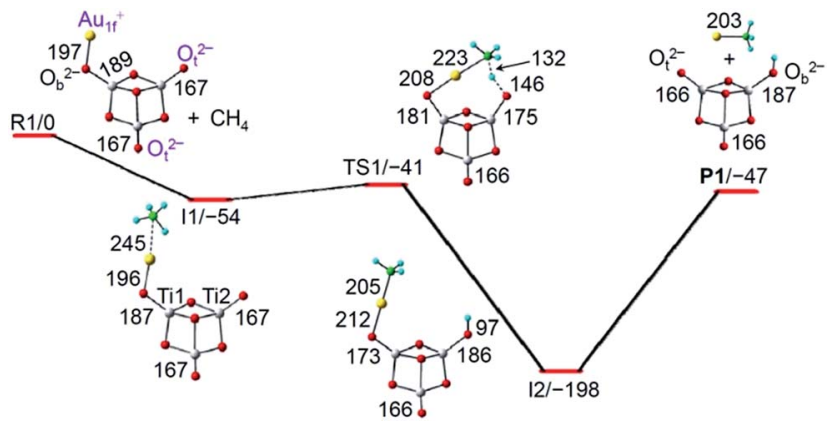

Fig. 2 TPSS functional calculated potential energy profile for $\mathrm{AuTi}_{3} \mathrm{O}_{7}{ }^{-}+\mathrm{CH}_{4} \rightarrow \mathrm{Ti}_{3} \mathrm{O}_{7} \mathrm{H}^{-}+\mathrm{AuCH}_{3}$. All of the species are in a singlet spin state. The dispersion corrected energies of the reaction intermediates (I1 and 12), transition state (TS1), and products (P1) with respect to the separated reactants (R1) are given in $\mathrm{kJ} \mathrm{mol}^{-1}$. Bond lengths are given in $\mathrm{pm}$. barrier of $13 \mathrm{~kJ} \mathrm{~mol}^{-1}$ which is surmountable by the binding energy of I1. The formation of I2 can release a high energy of $198 \mathrm{~kJ} \mathrm{~mol}^{-1}$, which is enough to evaporate the $\mathrm{AuCH}_{3}$ species rather than $\mathrm{Au}+\mathrm{CH}_{3}$ (endothermic by $244 \mathrm{~kJ} \mathrm{~mol}^{-1}$ ) from the reaction complex to form the experimentally observed $\mathrm{Ti}_{3} \mathrm{O}_{7} \mathrm{H}^{-}$ cluster (Fig. 1b).

The gold atom in the lowest-lying isomer of $\mathrm{AuTi}_{3} \mathrm{O}_{7}{ }^{-}$is onefold coordinated (Fig. 2). In a low-lying isomer of $\mathrm{AuTi}_{3} \mathrm{O}_{7}{ }^{-}$ (Fig. $\left.\mathrm{S}^{\dagger}\right)$, the $\mathrm{Au}^{+}$ion can be two-fold coordinated $\left(\mathrm{Au}_{2 \mathrm{f}}{ }^{+}\right)$. Such a cluster anion with $\mathrm{Au}_{2 \mathrm{f}}{ }^{+}$can hardly trap (binding energy is only $8 \mathrm{~kJ} \mathrm{~mol}^{-1}$ ) the reactant molecule $\mathrm{CH}_{4}$. The activation of $\mathrm{CH}_{4}$ by $\mathrm{AuTi}_{3} \mathrm{O}_{7}{ }^{-}$with the $\mathrm{Au}_{2 \mathrm{f}}{ }^{+}$is subject to an additional transformation so that the $\mathrm{Au}_{2 \mathrm{f}}{ }^{+}$ion becomes $\mathrm{Au}_{1 \mathrm{f}}{ }^{+}$(as in I1 of Fig. 2). The $\mathrm{Au}_{2 \mathrm{f}}{ }^{+} \rightarrow \mathrm{Au}_{1 \mathrm{f}}{ }^{+}$transformation has an overall positive barrier $\left(3 \mathrm{~kJ} \mathrm{~mol}^{-1}\right)$ which hinders subsequent methane activation, suggesting that the $\mathrm{AuTi}_{3} \mathrm{O}_{7}{ }^{-}$isomer with $\mathrm{Au}_{2 \mathrm{f}}{ }^{+}$corresponds to the un-reactive component $(13 \%)$ of $\mathrm{AuTi}_{3} \mathrm{O}_{7}{ }^{-}$in the experiments.

When one of the $\mathrm{O}_{\mathrm{t}}{ }^{2-}$ ions in the lowest-lying isomer of $\mathrm{AuTi}_{3} \mathrm{O}_{7}{ }^{-}$is replaced by a peroxide unit $\left(\mathrm{O}_{2}{ }^{2-}\right)$, a low-lying isomer of $\mathrm{AuTi}_{3} \mathrm{O}_{8}{ }^{-}$with $\mathrm{Au}_{1 \mathrm{f}}{ }^{+}$and $\mathrm{O}_{\mathrm{t}}{ }^{2-}$ ions can be formed (see I3 of Fig. 3). However, this isomer with $\mathrm{Au}_{1 \mathrm{f}}{ }^{+}$is less stable by $24 \mathrm{~kJ} \mathrm{~mol}^{-1}$ than the lowest-lying isomer of $\mathrm{AuTi}_{3} \mathrm{O}_{8}{ }^{-}$that contains an $\mathrm{Au}_{2 \mathrm{f}}{ }^{+}$ion (Fig. S6 ${ }^{\dagger}$ ). The activation of $\mathrm{CH}_{4}$ by the lowest-lying isomer of $\mathrm{AuTi}_{3} \mathrm{O}_{8}{ }^{-}$also involves the $\mathrm{Au}_{2 \mathrm{f}}{ }^{+} \rightarrow \mathrm{Au}_{1 \mathrm{f}}{ }^{+}$ conversion which is hindered by an overall positive reaction barrier $\left(1 \mathrm{~kJ} \mathrm{~mol}^{-1}\right)$. As a result, this lowest-lying isomer with $\mathrm{Au}_{2 \mathrm{f}}{ }^{+}$accounts for the $63 \%$ un-reactive component of the experimentally generated $\mathrm{AuTi}_{3} \mathrm{O}_{8}{ }^{-}$ions. The $37 \%$ reactive ions can then be assigned to the low-lying isomer with $\mathrm{Au}_{1 \mathrm{f}}{ }^{+}$and the reaction mechanism is shown in Fig. 3.

Similarly to $\mathrm{AuTi}_{3} \mathrm{O}_{7}{ }^{-}+\mathrm{CH}_{4}$ in Fig. 2, the $\mathrm{Au}_{1 \mathrm{f}}{ }^{+}$on $\mathrm{AuTi}_{3} \mathrm{O}_{8}{ }^{-}$ traps $\mathrm{CH}_{4}$ and delivers $\mathrm{CH}_{4}$ to be close to the $\mathrm{O}_{\mathrm{t}}{ }^{2-}$ ion for $\mathrm{C}-\mathrm{H}$ bond cleavage (I4 $\rightarrow$ TS3 $\rightarrow$ I5, Fig. 3). The large amount of

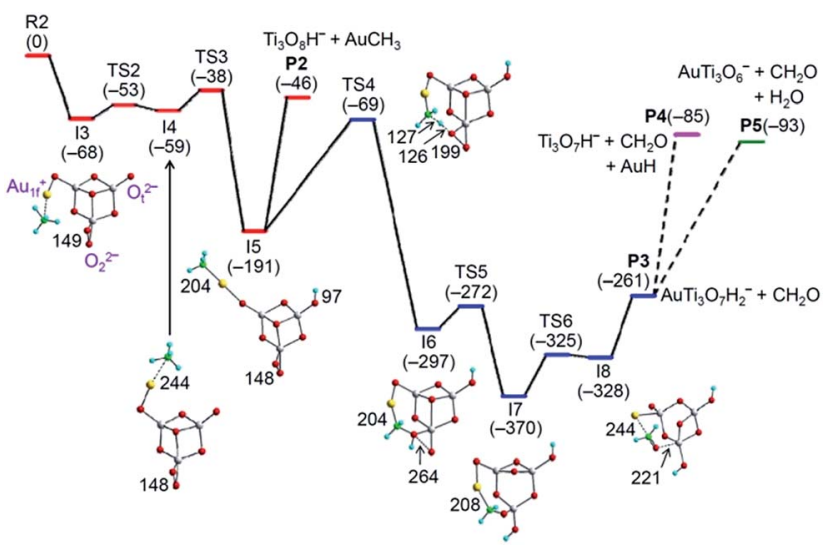

Fig. 3 TPSS functional calculated potential energy profile for $\mathrm{AuTi}_{3}-$ $\mathrm{O}_{8}{ }^{-}+\mathrm{CH}_{4}$ to generate the products $\mathrm{Ti}_{3} \mathrm{O}_{8} \mathrm{H}^{-}+\mathrm{AuCH}_{3}$ (P2), $\mathrm{AuTi}_{3}-$ $\mathrm{O}_{7} \mathrm{H}_{2}{ }^{-}+\mathrm{CH}_{2} \mathrm{O}(\mathrm{P} 3), \mathrm{Ti}_{3} \mathrm{O}_{7} \mathrm{H}^{-}+\mathrm{CH}_{2} \mathrm{O}+\mathrm{AuH}(\mathrm{P} 4)$, and $\mathrm{AuTi}_{3} \mathrm{O}_{6}{ }^{-}+$ $\mathrm{CH}_{2} \mathrm{O}+\mathrm{H}_{2} \mathrm{O}$ (P5). All of the species are in a singlet spin state. The dispersion corrected energies of the reaction intermediates (I3-18), transition states (TS2-TS6), and products (P2-P5) with respect to the separated reactants (R2) are given in $\mathrm{kJ} \mathrm{mol}^{-1}$. Bond lengths are given in pm. 
exothermic energy released $\left(191 \mathrm{~kJ} \mathrm{~mol}^{-1}\right)$ can evaporate the $\mathrm{AuCH}_{3}$ unit to produce $\mathrm{Ti}_{3} \mathrm{O}_{8} \mathrm{H}^{-}$(I5 $\rightarrow$ P2, Reaction (6)). Alternatively, I5 can overcome the energy barrier $\left(122 \mathrm{~kJ} \mathrm{~mol}^{-1}\right.$, I5 $\rightarrow$ TS4) involving the activation of a second $\mathrm{C}-\mathrm{H}$ bond by the $\mathrm{O}_{2}{ }^{2-}$ unit (I5 $\rightarrow$ TS4 $\rightarrow$ I6) to produce a neutral $\mathrm{CH}_{2} \mathrm{O}$ molecule and $\mathrm{AuTi}_{3} \mathrm{O}_{7} \mathrm{H}_{2}{ }^{-}$ions $(\mathrm{I} 6 \rightarrow$ TS5 $\rightarrow$ I7 $\rightarrow$ TS6 $\rightarrow$ I8 $\rightarrow$ P3, Reaction (7)). The formation of $\mathrm{AuTi}_{3} \mathrm{O}_{7} \mathrm{H}_{2}{ }^{-}$and $\mathrm{CH}_{2} \mathrm{O}$ is highly exothermic $\left(\Delta H_{0}=-261 \mathrm{~kJ} \mathrm{~mol}^{-1}\right)$, so the resulting $\mathrm{AuTi}_{3} \mathrm{O}_{7} \mathrm{H}_{2}{ }^{-}$ has enough internal energy to evaporate $\mathrm{AuH}$ and $\mathrm{H}_{2} \mathrm{O}$ (Fig. S7 $\dagger$ ) to form the product ions $\mathrm{Ti}_{3} \mathrm{O}_{7} \mathrm{H}^{-}$(Reaction (8)) and $\mathrm{AuTi}_{3} \mathrm{O}_{6}{ }^{-}$ (Reaction (9)), respectively. It can be seen that Reactions (7)-(9) all involve the generation of formaldehyde $\left(\mathrm{CH}_{2} \mathrm{O}\right)$ and the DFT calculations correctly predict that Reactions (6)-(9) are all kinetically and thermodynamically favorable. Furthermore, the lower energy of TS4 $\left(-69 \mathrm{~kJ} \mathrm{~mol}^{-1}\right)$ than that of P2 $(-46$ $\mathrm{kJ} \mathrm{mol}^{-1}$ ) can well rationalize the experimental branching ratios that show Reaction (6) as a minor channel.

In the reaction of $\mathrm{AuTi}_{3} \mathrm{O}_{8}{ }^{-}$with $\mathrm{CH}_{4}$, the $\mathrm{Au}_{1 \mathrm{f}}{ }^{+}$cation can also deliver $\mathrm{CH}_{4}$ to be close to the $\mathrm{O}_{2}{ }^{2-}$ anion to activate the first C-H bond of methane (Fig. S9†). Subsequent transformation to form the intermediate $\mathrm{I} 5$ is kinetically less favorable than the reaction path of Fig. 3. A reaction path to form I7 (Fig. S10†) is slightly more favorable than the path of Fig. 3 kinetically $\left(-45 \mathrm{~kJ} \mathrm{~mol}^{-1}\right.$ versus $-38 \mathrm{~kJ} \mathrm{~mol}^{-1}$ for the critical transition states). This alternative path has a very deep potential well $\left(209 \mathrm{~kJ} \mathrm{~mol}^{-1}\right)$ which can hinder the further transformation of the reaction complex into separate products and leads to the formation of the association species $\mathrm{AuTi}_{3} \mathrm{O}_{8} \mathrm{CH}_{4}{ }^{-}$. This result is consistent with the experimental observation that molecular association is a major reaction channel (41\%) for $\mathrm{AuTi}_{3} \mathrm{O}_{8}{ }^{-}+\mathrm{CH}_{4}$ (Fig. 1f).

\section{Discussion}

Many metal oxide clusters including homo-nuclear $\left(\mathrm{M}_{x} \mathrm{O}_{y}{ }^{ \pm}\right)$and hetero-nuclear oxide clusters $\left(\mathrm{M}_{x 1}^{1} \mathrm{M}^{2}{ }_{x 2} \mathrm{O}_{y}^{ \pm}\right)$have been found to react with methane under thermal collision conditions. ${ }^{8-11,22-25}$ All of the reactive oxide clusters were open-shell systems with oxygen radical centers and methane activation primarily followed Reaction (1). Recently, it has been demonstrated that the $\mathrm{PtAl}_{2} \mathrm{O}_{4}{ }^{-}$cluster can activate $\mathrm{CH}_{4}$ through Reaction (2) and then the oxygen radical accepts the transferred $\mathrm{H}$ atom. ${ }^{39}$ Herein, the $\mathrm{AuTi}_{3} \mathrm{O}_{7}{ }^{-}$and $\mathrm{AuTi}_{3} \mathrm{O}_{8}{ }^{-}$clusters are closed-shell systems (without radical oxygen species) and they activate methane through the new mechanism, Reaction (4). Previously, a few positively charged mononuclear species ${ }^{26,29}$ with closed-shell electronic structures were shown to activate methane through Reactions (2) and (3).

The observed reactivity of $\mathrm{AuTi}_{3} \mathrm{O}_{7}{ }^{-}$and $\mathrm{AuTi}_{3} \mathrm{O}_{8}{ }^{-}$with methane (Reactions (5)-(9)) can be closely related to the extraordinary properties of gold, and results from the strong relativistic effect on this element. ${ }^{40}$ The high electro-negativity of gold leads to a rather weak $\mathrm{Au}-\mathrm{O}$ chemical bond (bond energy of $\left.219 \mathrm{~kJ} \mathrm{~mol}^{-1}\right)^{41}$ so that the $\mathrm{O}-\mathrm{Au}_{1 \mathrm{f}}{ }^{+}$bond can be flexible for the delivery of $\mathrm{CH}_{4}$ to be close to $\mathrm{O}^{2-}$ (Fig. 2 and 3) or $\mathrm{O}_{2}{ }^{2-}$ (Fig. $\mathrm{S} 9 \dagger$ ) for $\mathrm{C}-\mathrm{H}$ activation. Moreover, the analogous $\mathrm{Au} / \mathrm{H}^{42}$ results in relatively strong $\mathrm{Au}-\mathrm{CH}_{3}\left(232 \mathrm{~kJ} \mathrm{~mol}^{-1}\right.$ by the TPSS functional) and $\mathrm{Au}-\mathrm{H}\left(292 \mathrm{~kJ} \mathrm{~mol}^{-1}\right.$ by the TPSS functional) bonds so that the evaporation of $\mathrm{AuCH}_{3}$ (Reactions (5) and (6)) and $\mathrm{AuH}$ (Reaction (8)) from the reaction complex is possible. Upon generation of the $\mathrm{CH}_{2} \mathrm{O}$ moiety in $\mathrm{AuTi}_{3} \mathrm{O}_{8}{ }^{-}+\mathrm{CH}_{4}$, the $\mathrm{Au}$ atom is bonded with the metal atom Ti (I8 of Fig. 3) and the gold atom becomes negatively charged $(-0.20 \mathrm{e})$, which is also a result of the relativistic effect. ${ }^{\text {00,43,44 }}$

In addition to the extraordinary properties of gold, the coparticipation of both $\mathrm{Au}_{1 \mathrm{f}}{ }^{+}$and $\mathrm{O}_{\mathrm{t}}^{2-}$ ions is very important for the activation of methane (Fig. 2 and 3). The reaction paths for the $\mathrm{C}-\mathrm{H}$ bond cleavage of $\mathrm{CH}_{4}$ by the single $\mathrm{Au}_{1 \mathrm{f}}{ }^{+}$cation and a single $\mathrm{O}_{\mathrm{t}}{ }^{2-}$ anion of $\mathrm{AuTi}_{3} \mathrm{O}_{7}{ }^{-}$have been also followed. These processes are subject to very high energy barriers (Fig. S11 $\dagger$ ). In addition, the reaction of $\mathrm{AuTi}_{3} \mathrm{O}_{7}^{-}$with $\mathrm{CH}_{4}$ on the triplet potential energy surface has also been calculated. It turned out that all of the triplet reactants, intermediates, and transition states are much higher $\left(>100 \mathrm{~kJ} \mathrm{~mol}^{-1}\right)$ in energy than the corresponding singlet counterparts. As a result, the cooperative activation by the $\mathrm{Au}_{1 \mathrm{f}}{ }^{+}$and $\mathrm{O}_{\mathrm{t}}{ }^{2-}$ ions, as shown in Fig. 2, is the only mechanism of methane activation by $\mathrm{AuTi}_{3} \mathrm{O}_{7}^{-}$.

To explore the excellent ability of the cooperative $\mathrm{Au}_{1 \mathrm{f}}{ }^{+}$and $\mathrm{O}_{\mathrm{t}}{ }^{2-}$ ions to promote methane activation by the closed-shell cluster anions of $\mathrm{AuTi}_{3} \mathrm{O}_{7}{ }^{-}$and $\mathrm{AuTi}_{3} \mathrm{O}_{8}{ }^{-}$under thermal collision conditions, variation of the geometrical structures of the reaction intermediates and the change of natural charge (Table S2 $\dagger$ ) as well as the Wiberg bond order (Table S3 $\dagger$ ) of critical atoms and chemical bonds have been analyzed for the reaction system of $\mathrm{AuTi}_{3} \mathrm{O}_{7}{ }^{-}+\mathrm{CH}_{4}$ (Fig. 2). During the course of $\mathrm{C}-\mathrm{H}$ bond cleavage (I1 $\rightarrow$ TS1 $\rightarrow$ I2), the electron population on the $\mathrm{CH}_{3}$ group and $\mathrm{Au}$ atom increases $\left(-0.11 \mathrm{e} \rightarrow-0.41 \mathrm{e}\right.$ for $\mathrm{CH}_{3}$ and $+0.44 \mathrm{e} \rightarrow+0.28 \mathrm{e}$ for $\mathrm{Au}$ ) and that on the transferring $\mathrm{H}$ decreases $(+0.18 \mathrm{e} \rightarrow+0.47 \mathrm{e})$, indicating that the $\mathrm{C}-\mathrm{H}$ bond may be cleaved in a heterolytic manner and the reaction may follow a Lewis acid-base pair mechanism taking into account that the separated $\mathrm{Au}_{1 \mathrm{f}}^{+}$and $\mathrm{O}_{\mathrm{t}}^{2-}$ ions in $\mathrm{AuTi}_{3} \mathrm{O}_{7}^{-}$can be considered as a Lewis acid and Lewis base, respectively. However, the change in the natural charges of the $\mathrm{CH}_{3}$ moiety and $\mathrm{H}$ is not very large (around 0.3e), additionally, the charge increase on the $\mathrm{H}$ is normal for a bond conversion of $\mathrm{C}-\mathrm{H} \rightarrow \mathrm{O}-\mathrm{H}$. In contrast to the Lewis acid-base mechanism, another mechanism of the flexible switch of the roles of the two $\mathrm{O}_{t}$ atoms in $\left[\mathrm{Ti}_{3} \mathrm{O}_{7}\right]^{2-}$ which enables the favorable $\mathrm{C}-\mathrm{H}$ activation is proposed from a bonding point of view. The reactant of $\mathrm{AuTi}_{3} \mathrm{O}_{7}{ }^{-}$can be viewed as $\mathrm{Au}^{+}\left[\mathrm{Ti}_{3} \mathrm{O}_{7}\right]^{2-}$, in which $\mathrm{Au}^{+}(+0.42 \mathrm{e})$ is attached to one of the $\mathrm{O}_{\mathrm{t}}$ in $\left[\mathrm{Ti}_{3} \mathrm{O}_{7}\right]^{2-}(-1.42 \mathrm{e})$ with a bond strength of $1058 \mathrm{~kJ} \mathrm{~mol}^{-1}$ and the $\mathrm{O}_{\mathrm{t}}$ becomes a bridging-bonded oxygen $\left(\mathrm{O}_{\mathrm{b}}\right.$, as marked in Fig. 2). During the $\mathrm{C}-\mathrm{H}$ activation, such $\mathrm{O}_{\mathrm{b}}$ releases gold to bond with the $\mathrm{CH}_{3}$ moiety and the $\mathrm{O}_{\mathrm{b}}$ itself switches to $\mathrm{O}_{\mathrm{t}}$ after $\mathrm{AuCH}_{3}$ evaporation (Fig. 2). At the same time, a different $\mathrm{O}_{\mathrm{t}}$ in $\left[\mathrm{Ti}_{3} \mathrm{O}_{7}\right]^{2-}$ switches to $\mathrm{O}_{\mathrm{b}}$ after attaching to $\mathrm{H}^{+}(+0.46 \mathrm{e})$ with a much stronger bond strength of $1710 \mathrm{~kJ} \mathrm{~mol}^{-1}$ (Fig. 2). Thus, the overall increased bond strengths in the products drive the $\mathrm{C}-\mathrm{H}$ activation thermodynamically. The switch of the roles of the two $\mathrm{O}_{\mathrm{t}}$ in $\left[\mathrm{Ti}_{3} \mathrm{O}_{7}\right]^{2-}$ can also be evidenced by the change of the Wiberg bond order of Ti- $\mathrm{O}_{\mathrm{t}}$ (Table S3 $\uparrow$ ). The Ti1- $\mathrm{O}_{\mathrm{t}}$ and Ti2$\mathrm{O}_{t}$ bonds (Fig. 2) gradually switch from single/double bonds $(187 / 167 \mathrm{pm})$ in the reactant to double/single bonds (166/187 $\mathrm{pm})$ in the product. This mechanism suggests that the $\mathrm{C}-\mathrm{H}$ 
bond may be cleaved in a homolytic manner, namely, hydrogen atom transfer (HAT).

The identification of the Lewis acid-base mechanism or HAT for $\mathrm{AuTi}_{3} \mathrm{O}_{7}{ }^{-}+\mathrm{CH}_{4}$ relies on the transfer mode of one electron $\left(\mathrm{e}^{-}\right)$and one proton $\left(\mathrm{H}^{+}\right)$of a $\mathrm{H}$ atom. HAT is characterized by the transfer of the electron and proton to a single site. In contrast, a Lewis acid-base mechanism corresponds to the transfer of the electron and proton to different acceptor sites. Such a transfer mode can be called an electron-proton transfer (EPT). ${ }^{45}$ It was proposed that a key element in the theoretical characterization of the mechanisms of proton and electron transfer is the formulation of their localized diabatic states. ${ }^{46}$ However, the electron and proton described by standard quantum mechanical methods tend to be delocalized, and the analysis of the electron or proton acceptors such as a molecular orbital or a chemical bond depends on the adopted computational level of theory. ${ }^{45}$ Consequently, it is hard to distinguish exactly the two proposed mechanisms of $\mathrm{AuTi}_{3} \mathrm{O}_{7}{ }^{-}+\mathrm{CH}_{4}$ at the present level of theory. More advanced methods such as multistate DFT, in which the electron and proton localized diabatic configurations can be constructed through blocklocalization of Kohn-Sham orbitals, should be employed to study the potential energy surfaces of the HAT and EPT, which may provide clues to recognize the mechanistic details of our reaction systems.

\section{Conclusions}

The reactions of methane with negatively charged titanium oxide clusters doped with single gold atoms, $\mathrm{AuTi}_{3} \mathrm{O}_{7}{ }^{-}$and $\mathrm{AuTi}_{3} \mathrm{O}_{8}{ }^{-}$, have been identified by mass spectrometry and quantum chemistry calculations. To the best of our knowledge, this is the first example of the thermal activation and transformation of methane by atomic cluster anions with closedshell electronic structures. Unlike the previously reported three general mechanisms including hydrogen atom abstraction, oxidative addition, and $\sigma$-bond metathesis for methane activation by atomic clusters, the cooperation of the separated $\mathrm{Au}^{+}$ and $\mathrm{O}^{2-}$ induces the cleavage of the first $\mathrm{C}-\mathrm{H}$ bond of methane for $\mathrm{AuTi}_{3} \mathrm{O}_{7}{ }^{-}$and $\mathrm{AuTi}_{3} \mathrm{O}_{8}{ }^{-}$clusters. Further activation of the second $\mathrm{C}-\mathrm{H}$ bond of methane on the oxygen-rich system of $\mathrm{AuTi}_{3} \mathrm{O}_{8}{ }^{-}$leads to the formation of the stable organic compound formaldehyde $\left(\mathrm{CH}_{2} \mathrm{O}\right)$. The observed unique reactivity of $\mathrm{AuTi}_{3} \mathrm{O}_{7}{ }^{-}$and $\mathrm{AuTi}_{3} \mathrm{O}_{8}{ }^{-}$toward methane results from the strong relativistic effect on the gold element. This study not only serves as an important step in understanding that closedshell species on metal oxides can be reactive enough to facilitate thermal $\mathrm{H}-\mathrm{CH}_{3}$ bond cleavage, but also provides molecularlevel insights into the design of active sites on metal oxide supported gold catalysts to activate and transform methane.

\section{Acknowledgements}

This work is supported by the National Natural Science Foundation of China (No. 21273247, 21325314, and 21573247), the Major Research Plan of China (No. 2013CB834603), and the
Strategic Priority Research Program of the Chinese Academy of Sciences (No. XDA09030101).

\section{Notes and references}

1 R. H. Crabtree, Chem. Rev., 1995, 95, 987-1007.

2 J. H. Lunsford, Catal. Today, 2000, 63, 165-174.

3 R. A. Periana, O. Mironov, D. Taube, G. Bhalla and C. Jones, Science, 2003, 301, 814-818.

4 Q. Zhu, S. L. Wegener, C. Xie, O. Uche, M. Neurock and T. J. Marks, Nat. Chem., 2013, 5, 104-109.

5 X. Guo, G. Fang, G. Li, H. Ma, H. Fan, L. Yu, C. Ma, X. Wu, D. Deng, M. Wei, D. Tan, R. Si, S. Zhang, J. Li, L. Sun, Z. Tang, X. Pan and X. Bao, Science, 2014, 344, 616-619.

6 J. Gao, Y. Zheng, J.-M. Jehng, Y. Tang, I. E. Wachs and S. G. Podkolzin, Science, 2015, 348, 686-690.

7 S. Arndt, G. Laugel, S. Levchenko, R. Horn, M. Baerns, M. Scheffler, R. Schlögl and R. Schomäcker, Catal. Rev.: Sci. Eng., 2011, 53, 424-514.

8 N. Dietl, M. Schlangen and H. Schwarz, Angew. Chem., Int. Ed., 2012, 51, 5544-5555.

9 J. Roithová and D. Schröder, Chem. Rev., 2010, 110, 11701211.

10 X.-L. Ding, X.-N. Wu, Y.-X. Zhao and S.-G. He, Acc. Chem. Res., 2012, 45, 382-390.

11 G. de Petris, A. Troiani, M. Rosi, G. Angelini and O. Ursini, Chem.-Eur. J., 2009, 15, 4248-4252.

12 R. Liyanage, X.-G. Zhang and P. B. Armentrout, J. Chem. Phys., 2001, 115, 9747-9763.

13 U. Achatz, C. Berg, S. Joos, B. S. Fox, M. K. Beyer, G. NiednerSchatteburg and V. E. Bondybey, Chem. Phys. Lett., 2000, 320, 53-58.

14 S. M. Lang, T. M. Bernhardt, R. Barnett and N. U. Landman, Angew. Chem., Int. Ed., 2010, 49, 980-983.

15 D. J. Harding, C. Kerpal, G. Meijer and A. Fielicke, Angew. Chem., Int. Ed., 2012, 51, 817-819.

16 C. Adlhart and E. Uggerud, Chem. Commun., 2006, 25812582.

17 A. W. Castleman Jr, Catal. Lett., 2011, 141, 1243-1253.

18 S. Yin and E. R. Bernstein, Int. J. Mass Spectrom., 2012, 321322, 49-65.

19 R. A. J. O'Hair, Int. J. Mass Spectrom., 2015, 377, 121-129.

20 M. Diefenbach, M. Brönstrup, M. Aschi, D. Schröder and H. Schwarz, J. Am. Chem. Soc., 1999, 121, 10614-10625.

21 C. J. Cassadyt and S. W. McElvany, J. Am. Chem. Soc., 1990, 112, 4188-4191.

22 H. Schwarz, Isr. J. Chem., 2014, 54, 1413-1431.

23 S. Feyel, J. Döbler, D. Schröder, J. Sauer and H. Schwarz, Angew. Chem., Int. Ed., 2006, 45, 4681-4685.

24 S. Feyel, J. Döbler, R. Höckendorf, M. K. Beyer, J. Sauer and H. Schwarz, Angew. Chem., Int. Ed., 2008, 47, 1946-1950.

25 X.-N. Wu, X.-N. Li, X.-L. Ding and S.-G. He, Angew. Chem., Int. Ed., 2013, 52, 2444-2448.

26 M. Armélin, M. Schlangen and H. Schwarz, Chem.-Eur. J., 2008, 14, 5229-5236.

27 P. B. Armentrout and J. L. Beauchamp, Acc. Chem. Res., 1989, 22, 315-321. 
28 M. Schlangen and H. Schwarz, Helv. Chim. Acta, 2008, 91, 2203-2210.

29 R. Kretschmer, M. Schlangen and H. Schwarz, Angew. Chem., Int. Ed., 2013, 52, 6097-6101.

30 P. J. Roach, W. H. Woodward, A. W. Castleman Jr, A. C. Reber and S. N. Khanna, Science, 2009, 323, 492-495.

31 A. C. Reber, P. J. Roach, W. H. Woodward, S. N. Khanna and A. W. Castleman Jr, J. Phys. Chem. A, 2012, 116, 8085-8091.

32 W. H. Woodward, A. C. Reber, J. C. Smith, S. N. Khanna and A. W. Castleman Jr, J. Phys. Chem. C, 2013, 117, 7445-7450.

33 Z. Luo, J. C. Smith, C. Berkdemir and A. W. Castleman Jr, Chem. Phys. Lett., 2013, 590, 63-68.

34 J.-H. Meng and S.-G. He, J. Phys. Chem. Lett., 2014, 5, 38903894.

35 Z. Yuan, Z.-Y. Li, Z.-X. Zhou, Q.-Y. Liu, Y.-X. Zhao and S.-G. He, J. Phys. Chem. C, 2014, 118, 14967-14976.

36 G. Kummerlöwe and M. K. Beyer, Int. J. Mass Spectrom., 2005, 244, 84-90.
37 J.-B. Ma, B. Xu, J.-H. Meng, X.-N. Wu, X.-L. Ding, X.-N. Li and S.-G. He, J. Am. Chem. Soc., 2013, 135, 2991-2998.

38 S. Grimme, J. Antony, S. Ehrlich and H. Krieg, J. Chem. Phys., 2010, 132, 154104.

39 Y.-X. Zhao, Z.-Y. Li, Z. Yuan, X.-N. Li and S.-G. He, Angew. Chem., Int. Ed., 2014, 53, 9482-9486.

40 P. Pyykkö, Angew. Chem., Int. Ed., 2004, 43, 4412-4456.

41 J. B. Pedley and E. M. Marshall, J. Phys. Chem. Ref. Data, 1983, 12, 967-1031.

42 L. S. Wang, Phys. Chem. Chem. Phys., 2010, 12, 8694-8705.

43 X.-N. Li, Z. Yuan and S.-G. He, J. Am. Chem. Soc., 2014, 136, 3617-3623.

44 M. Jansen, Chem. Soc. Rev., 2008, 37, 1826-1835.

45 A. K. Harshan, T. Yu, A. V. Soudackov and S. HammesSchiffer, J. Am. Chem. Soc., 2015, 137, 13545-13555.

46 A. Cembran, M. R. Provorse, C. Wang, W. Wu and J. Gao, J. Chem. Theory Comput., 2012, 8, 4347-4358. 